\title{
CONSTRUCTION OF CIBEST MODEL AS MEASUREMENT OF POVERTY AND WELFARE INDICES FROM ISLAMIC PERSPECTIVE
}

\author{
Irfan Syauqi Beik \& Laily Dwi Arsyianti ${ }^{1}$
}

\begin{abstract}
Construction of CIBEST Model as Measurement of Poverty and Welfare Indices from Islamic Perspective. One of the major challenges faced by most of the Islamic countries is poverty. This paper attempts to construct the concept of poverty and welfare standards based on Islamic perspective. The study tries to cover both material and spiritual dimensions. These standards are based on CIBEST Quadrant, which is divided into four quadrants: welfare quadrant (I), material poverty quadrant (II), spiritual poverty quadrant (III) and absolute poverty quadrant (IV). Determination of these quadrants is resulted from criteria and indicators of basic material needs and basic spiritual needs. By using household as unit of analysis, this study is able to developCIBEST Model comprising welfare index, material poverty index, spiritual poverty index, and absolute poverty index. Mathematical formula and illustration of the indices are also elaborated to strengthen the concept.
\end{abstract}

Keywords: Basic Needs Approach, Poverty, Welfare Indices

\begin{abstract}
Abstrak. Konstruksi atas Model CIBEST Sebagai Pengukuran atas Kemiskinan dan Kesejahteraan dalam Perspektif Islam. Salah satu permasalahan penting yang dihadapi negara-negara Islam adalah kemiskinan. Tulisan ini berupaya untuk mengkonstruksi konsep kemiskinan dan kesejahteraan menurut perspektif ajaran Islam. Penelitian yang dilakukan, berupaya untuk mengkombinasikan dimensi material dan dimensi sipiritual. Alat ukur yng digunakandalam studi ini didasarkan pada kuadran CIBEST yang terbagi menjadi empat kuadran, yaitu : kuadran sejahtera (I), kuadran kemiskinan material (II), kuadran kemiskinan spiritual (III), dan kuadran kemiskinan absolut (IV).Penetapan kuadran ini dibuat berdasarkan kriteria dan indikator kebutuhan dasar material dan kebutuhan dasar spiritual. Dengan menggunakan rumahtangga sebagai unit analisis, penelitian ini berhasil memformulasikan model CIBEST yang terdiri dari indeks kesejahteraan, indeks kemiskinan material, indeks kemiskinan spiritual dan indeks kemiskinan absolut. Formula matematika dan ilustrasi dari setiap indeks juga dielaborasi secara detil untuk memperkuat konsep yang ada.
\end{abstract}

Kata kunci: Pendekatan Kebutuhan Dasar, Kemiskinan, Indeks Kesejahteraan

First draft: October, 3rd 2014, Revision: December, 5th 2014, Accepted: December, $20^{\text {th }}$ 2014

1 Center of Islamic Business and Economic Studies, Bogor Agricultural University, Jl. Raya Darmaga Kampus IPB Darmaga, Bogor

Email : irfan_beik@ipb.ac.id, arsyianti@ipb.ac.id 


\section{Introduction}

Poverty remains a major issue faced by the Islamic world presently. The term 'poverty', however, could not be defined in a single term, which prevails across the globe. It is because of the differences in many aspects, such as demographical factors, geographical location, cultural diversity, etc., although various scholars have attempted to define poverty from different angles and perspectives. They also have tried to accommodate these differences in their definition of poverty. Debate on this issue still continues including debate on measurement and criteria used to define poverty.

Despite these difficulties in constructing single definition of poverty, real practices taking place in different countries seem to provide the fact that poverty is always related with inability of certain group of people to fulfill their basic needs. This group of people is called the poor. Definition of the poor is always connected with a standard of measurement called poverty line. It is a line that is measured in terms of minimum income, which must be earned by a person. If a person earns income below the line, he will fall under the poor category. For example, in Indonesia, the National Board of Statistics (known as Badan Pusat Statistik- abbreviated as BPS) has determined poverty line to be equal to Rp 293,000 (USD 25.04) per capita per month in 2014. The number of the poor living below the line is estimated to reach 28.55 million people (National Board of Statistics, 2014). This poverty line may change usually on annual basis. Similarly, the World Bank use USD 2 per capita per day as basic standard of absolute poverty, meaning that, earning income below the standard will put someone in the category of absolute poor.

Islam actually pays great concern on the issue of poverty. As a comprehensive religion covering all aspects of life, Islam has clear rules and guidance regarding this matter. There are many ayah and hadith which can be made as source of reference. Similarly, there are a large number of literatures discussing the concept of poverty from Islamic perspective, which are written by classical as well as contemporary Islamic scholars.

It is interesting to note that most of the discussion on poverty from Islamic perspective is based on the concept of maqasid al shariah. The term 'maqasid', which is the plural form of the word 'maqsad', reflects the basic objectives of revelation of Islamic teaching. Chapra (2008) states that the maqasid al shariahhave been either stated directly from the Quran or inferred from these by a number of scholars. All of these address the basic objective of the shariah, which is to serve the interests of all human beings and to save them from harm (Chapra, 2008).

One of the most prominent classical Islamic scholars in the history, Imam 
al-Ghazali, has classified maqasid al shariah into five major categories. Those are protection of faith ( $h i f z$ al-din), protection of human self (hifz al-nafs), protection of intellect (hifz al-aql), protection of posterity (hifz al-nasl) and protection of wealth ( hifz al-maal). These are basic elements in promoting the well-being of the people. Imam al-Shatibi furthermore classified the maqasid into three broad categories, i.e. daruriyyat (essentials), hajiyyat (supporting) and tabsiniyyat (embellishment). To alShatibi, al-Ghazali's five safeguarding fall under daruriyyat category.

This paper attempts to construct this standard of measurement in the form of welfare index and poverty index. These indices will be based on certain criteria, which are derived from the Quran and Sunnah and compared with current practices in the contemporary Islamic economies. The paper comprises five sections including introduction as the first one. Second section shall elaborate overview on the conceptual framework of poverty from Islamic perspective. Section three discusses existing models of poverty standard and measurement by taking the case of Indonesia. Indonesia is purposively selected since it represents the most populous Muslim country in the world. Section four proposes model of welfare and poverty indices as standard of measurement combined with illustration on how to use those indices. This section will be started by elaborating conceptual foundation of the proposed model. Last section concludes the paper.

\section{The Poverty Concep on Islamic Approach}

As mentioned in the previous section poverty basically is a multidimensional concept. Shirazi (1994), Narrayan (2000), and Pramanik (1993, 1998) are of the view that poverty basically is an imprecise term. It is not possible to capture the idea of poverty based on unidirectional approach. They suggest that poverty is typically used to refer to a situation where individuals do not have sufficient resources to cover their basic needs to lead a reasonably comfortable life, not only by economic but also by social, psychological and even spiritual dimensions.

Suharto (2009) argues that while some economists discuss the concept of poverty based on subjective and comparative approach, some others favor moral and evaluative approach. Poverty being mostly associated with economic dimension, it is, indeed, related to other dimensions including social, cultural, institutional, and structural. Al-Ghazali (1980) defines poverty as a state of not being able to fulfil one's needs. Inability to satisfy what is not needed is not poverty. If the needed items are available and affordable by a person, then he will not be treated as poor person. Al-Ghazali divides poverty into two parts: first, poverty in relation to material needs; and second, poverty in relation to spiritual needs. Similar argument is also made by Ahmed (2004). He says that poverty does not only represent deprivation of goods 
and services, but also lack of poverty in spirit. Even Rehman (1980) argues that in Islam individuals can improve their spiritual life by improving their material life.

Al-Ghazali further states that each and every being that exists is poor, except for the eternal being, Allah. This is the meaning of the verse (47:38) "wa Allah alghaniyywaantum al-fuqara", which means 'and Allah is rich and you all are poor'. To him, this is an absolute poverty (faqrmutlaq), which has both material and spiritual dimensions. In response to Al-Ghazali's argument, Sadeq (1992) says that the term faqrmutlaqin contemporary economics refers to two different meanings. First, it refers to a state below some absolute level of income that could purchase some minimal level of sustenance. Second, it refers to poverty of the individuals or households in absolute terms without reference to their relative condition as compared to others. In this sense absolute poverty is used against relative poverty.

Ibn al-Qayyim al-Jauziyyah (1293 - 1350 AD), on the other hand, denies the relationship between poverty and $z u h d$, an important Islamic value misconstrued as renunciation of wealth and the good things of life. He insists that $z u b d$ is not poverty. It is an attitude of mind which purifies soul from the lust for worldly things and from making them the objectives of life. He argues that affluence is more preferable provided it accompanies gratitude to Allah and the fulfilment of one's obligations toward fellow human beings (Islahi, 1992).

The concept of poverty is indeed determined by the definition of the poor (faqir) and the needy (miskeen). Hence, Shirazi (1994) argues that the jurists from the four prominent schools have different ideas in this regard. According to Shafi'ite and Hanbalite schools, a person is called faqir if he possesses no wealth and earning, or earns income and wealth which satisfy less than half of his needs. A person is called miskeenif he earns income and wealth which satisfy more than half, but less than 100 percent of his needs. On the other hand, the other two schools, i.e. Hanafite and Malikite, have the opposite perceptions. However, Shirazi (1994) argues that opinions are not much different from practical point of view. It is because both are not in a position to meet their needs without the provision of assistance provided by the society or state.

Hafidhuddin (2013) stated that poverty is part of God's law in this life. As mentioned in the Quran (43:32) that Allah SWT has determined people's livelihood. Some of them are lifted up higher than the others, so that they can synergize and help each other. Islam, hence, does not discuss on how to eliminate poverty totally. Rather, it discusses how to reduce the excessive gap between the rich and the poor.

Hafidhuddin also argues that the poor having good morals are one of important pillars of development. He cites Ali bin Abi Thalib who states that the 
resilience of the world and society affairs is due to five pillars: knowledge of the ulama, fair and just rulers, generosity of the rich, honesty and integrity of the employees and bureaucracy, and prayer of the poor. He concludes that poverty could not be observed only from material perspective, but also from spiritual perspective.

\section{Existing Model of Poverty Standard: Case of Indonesia}

The literatures above have demonstrated that poverty from Islamic perspective covers both material and spiritual dimensions. Another important issue is how to measure poverty and on what basis this poverty is determined. In this regard, some attempts have been made by various institutions and scholars. This section elaborates at least three models which have been applied, especially with the reference to Indonesia. Those are model of consumption or basic needs approach, model of decent living standard, and model of family welfare.

The National Board of Statistics of Indonesia uses consumption model or basic needs approach as basis for determining poverty standard. The model comprises food consumption and non-food consumption standard. Food consumption is based on the consumption of 2,100 kilo calories per capita per day, and these calories are valued in terms of money. If a person consumes less than this calorie standard, then he will be categorized as poor. Therefore, this standard is also called as food poverty line.

In Indonesia, non-food consumption for rural areas is different from urban areas. There are 47 commodities for rural areas while urban areas have 51 commodities (Beik, 2013). Similarly, these commodities are valued in terms of money. The standard resulted from this valuation is called non-food poverty line. Summation of food poverty line and non-food poverty line forms national poverty line. According to the September 2013 data, contribution of food poverty line towards national poverty line reaches 73.43 percent. The rest is contributed by non-food poverty line (National Board of Statistics, 2014). Unit of analysis in this approach is individual basis. However, spiritual dimension is not considered by this approach. It merely focuses on material aspect.

Another approach is the one that has been developed by the Ministry of Labor and Transmigration of Indonesia. The Ministry has issued an index of decent living standard. Initially, it is used as basis for determining minimum wage standard for labor. This minimum wage is decided by Wage Council which operates in every city and regency throughout the country (Beik, 2012). This council consists of tripartite: government representative, labor representative and industrial representative.

Index of decent living standard is designed to observe capability of a person to fulfill his basic needs, such as food, clothes and housing needs. The index comprises 
seven basic elements: first, food and drink; second, clothes; third, housing; fourth, education; fifth, health; sixth, transportation; and seventh, recreation and saving. Survey is always conducted annually as media of information on real prices of the basic elements. Nevertheless, this index does not accommodate religiosity and freedom to express and to practice religious obligation. When the monetary value of the index has been decided by the Wage Council, labor office of city government must ensure that all industries obey the decision. Unit of analysis of this index is individual basis.

Unlike the previous two standards, the National Coordinating Agency of Family Planning Program of Indonesia (known as Badan Koordinasi Keluarga Berencana Nasional, abbreviated as BKKBN) applies the model of family welfare, which has been replicated in more than 90 countries globally (Alimoeso, 2014). The model is designed on household or family basis. This is totally different from the previous two approaches, which are individual-based. BKKBN classifies family into five types: pre-prosperous family, prosperous family I, prosperous family II, prosperous family III, and prosperous family III-plus.

Pre-prosperous family is considered as the poorest of the poor or the hardcore poor, while prosperous family I is classified as the poor. Prosperous family I is used as the family poverty standard. Criteria employed to determine poverty standard for family is qualitative in nature. BKKBN has determined six criteria, which are based on the basic needs approach. Those are: first, food consumption at least twice a day although with minimum calories; second, family members have different clothes for school, work, travelling and during their stay at home; third, residential house has good roof, floor and wall; fourth, treatment for family member suffering illness is conducted at health facilities provided by government; fifth, when parents are still in productive age and willing to join family planning program, they consult official contraception service facilities; and sixth, all children aging between 7 to 15 years old are schooling. Inability to fulfill at least one of these criteria will place a family in the category of hardcore poor or pre-prosperous family (Alimoeso, 2014).

BKKBN further determines the indicators of family that has been released from poverty. These indicators are used as basis to observe whether a poor family has changed their status from prosperous family I to prosperous family II. Criteria of the prosperous family II comprise eight criteria, which are: first, family members are able to perform religious obligation; second, entire family members consume meat, egg and fish at least once in a week; third, all family members at least purchase one new clothes in a year; fourth, the floor size of the house at least $8 \mathrm{~m}^{2}$ for each family member; fifth, family members for the last three months are in a good health condition so that they are able to perform their functions and duties; sixth, at least 
there exists one family member who work to earn sufficient income; sevent, all family members whose age are between 10-60 years old able to read and write in Indonesian language; and eight, parents in productive age with 2 or more children use contraception medicine or other tools of contraception (Alimoeso, 2014).

\section{Cibest Model on Islamic Poverty and Welfare Indices}

Various attempts have been made in order to construct poverty and welfare standards from Islamic perspective. One of the most significant efforts in the contemporary economy, which has been used in the real practice of zakat distribution, is the concept of Lembaga Zakat Selangor (Selangor Zakat Institution in Malaysia, abbreviated as LZS). LZS has used had al-kifayahapproach as the basis to determine whether a family or a person is eligible to receive zakat or not. Had al-kifayabby definition is standard of minimum needs, which must be fulfilled by a family. Inability to fulfill these needs will place family in poor status and hence, that family is eligible to receive zakat fund.

In this concept, LZS has divided a family into five groups: head of household, working adult, unemployed adult, children within the 7-17 years old age group, and children within the 1-6 age group (Rasoolet al, 2011). The poor standard is determined by the ability of a household to satisfy their basic needs (daruriyyah), which consist of foods, clothes, houses, health, and education. Thus, by applying had al-kifayah, a household is eligible to receive zakat fund only if their monthly income is less than RM 1,650 -this is 2011 data. In addition, if there were disable or people with severe illness in the family members, the minimum limit would be raised to RM 2,240/month/household (Rasoolet al, 2011).

The concept applied by LZS should be greatly appreciated since it attempts to go beyond poverty line income (PLI) standard, which has been applied across the globe by many governments. Sometimes the value of PLI in many countries is too low compared to their economy condition. Nevertheless, the LZS concept is still focusing on material aspect. Had al-kifayahis merely translated into basic needs, which do not consider spiritual aspect. In this paper, we attempt to construct poverty and welfare standards which cover both material and spiritual aspects. These standards will be reflected in the poverty and welfare indices, which are measurable and comparable.

Basic spiritual needs could be defined as the needs to implement ibaadah (worship) to Allah SWT. BKKBN as mentioned in the third section includes capability to undertake religious obligation as an indicator of welfare family. However, BKKBN does not elaborate further criteria of this capability. This paper, hence, proposes that the concept of this 'capability' should be indicated by three factors, 
i.e. ability, strong will, and freedom. These three factors are strongly interrelated. The absence of one or more factors will reduce capability of a person to perform ibaadah. If this happens, a person may have poor spiritual condition. For example, the absence of willingness to pray will reduce capability to undertake worship.

Furthermore, there are five variables of basic spiritual needs: implementation of shalat(prayer), saum(fasting), zakat, household environment, and government policy environment. These variables will be used as basis in the calculation of spiritual poverty index, which will be discussed later. As already known, prayer, fasting and zakat are part of Islamic pillars which must be fully implemented by Muslims, in addition to declaration of shahadahand hajj (pilgrimage). Reluctance to perform these ibaadah may reduce the quality of iman(faith). There is no excuse for all Muslims, especially those who are included in the category of mukallaf, to avoid these religious obligations.

Pilgrimage, on the other hand, is excluded from the variables affecting spiritual poverty index. It is because pilgrimage requires certain conditions, such as availability of huge financial resources. Another argument, when a person has strong awareness to undertake prayer, zakat and fasting obligations, he will automatically have awareness to perform hajj subject to his capability in removing financial constraint. Spiritually, this person is rich. Therefore, the focus should be directed to prayer, fasting and zakat.

Fourth variable is household environment. It is extremely important to have supportive household environment in fulfilling religious obligations. Unsupportive household environment may create spiritually poor person. For example, when the husband has a very liberal opinion in which he disagrees with the existence of prayer, most probably the wife will face difficulty in performing prayer regularly. She may fall to spiritually poor person status.

Similarly, the fifth variable, i.e. government policy environment, is also affecting spiritual condition of the people. Although not all ibaadah require specific government regulation, but the presence of supportive government policy environment is highly needed. This environment will determine the degree of freedom to execute Islamic teaching in certain societies. Unsupportive government policy environment may produce spiritually poor people. For example, although Prayer Act is not needed, but when government attempts to secularize the people by prohibiting prayer or by not providing sufficient prayer room in government offices, it may create spiritually poor bureaucrats. Hence, this variable cannot be ignored.

Unit of analysis proposed is based on household rather than individual. It is because in Islam, the smallest unit of society is household or family. Given this reason, hence in this paper, LZS (Lembaga Zakat Selangor)division of household is 
adopted with modification. This modification could be observed in the presence of teenagers group. The main reason is due to different characteristic between teenagers and children, especially with respect to emotional maturity and puberty period. Hence, the household is divided into six groups: head of the household, working adult, unemployed adult ( $>18$ years old), teenagers between $15-18$ years old group, children within 7-14 years old group, and children within $\leq 6$ years old group.

Head of the household is defined as a person who is responsible to fulfill basic needs of the entire household members. The household head could be father, single mother (widow or divorced mother), or other responsible person in the absence of parents, such as elder brother or sister. Working adult is defined as a person who is working but still under the responsibility of household head. This could be a working wife, son, daughter, or someone else, such as adopted son who has professional job.

Unemployed adult, furthermore, is defined as a person who is under the responsibility of household head but not working, such as housewife and unemployed son. Teenager refers to a person attending school or school dropout teenage within the age group 15-18 and in puberty period. This group could be included in the category of mukallaf.

Child within the age group 7-14 is defined as the one who attend school or school dropout child. Lastly, child within the age group $\leq 6$ refers to the one whose age is less than or equal to 6 years old. These last two groups are not included in the category of mukallaf.

From the concept of fulfillment of basic spiritual needs and material needs, we can construct typology of the household in the form of CIBEST quadrant. There are four typologies of household based on their ability to fulfill basic spiritual needs and basic material needs. It could be observed in the following Figure 1.

Figure 1. CIBEST Quadrant

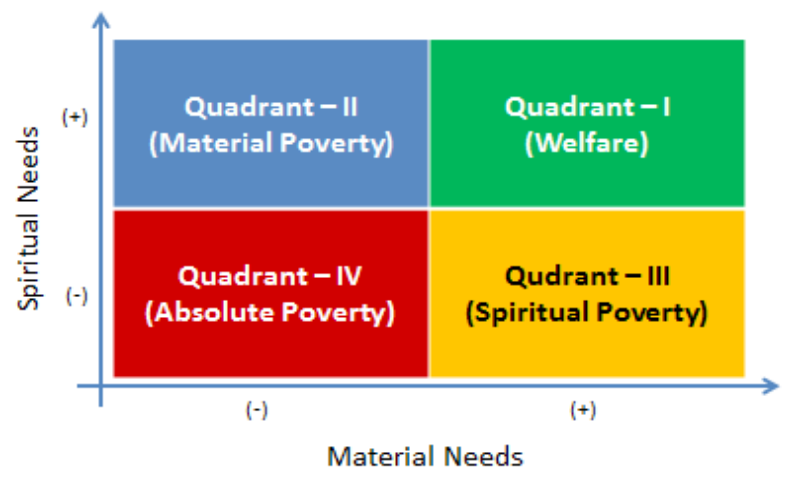


Based on the Figure 1, CIBEST quadrant is divided into four quadrants. Material needs are shown by horizontal axis, while spiritual needs are represented by vertical axis. The (+) sign in the horizontal axis indicates that material needs have been sufficiently fulfilled by the household while (-) sign indicates the opposite, i.e. the household is lack of material needs. Similarly, the $(+)$ sign in the vertical axis portrays the ability of household to fulfill their spiritual needs while the (-) sign shows the opposite condition.

In the first quadrant, it can be observed that the household is in the positive areas of both material needs and spiritual needs. It means that the household is spiritually and materially rich. Hence, this area is called welfare quadrant. The second quadrant is combination of positive spiritual needs and negative material needs. This indicates that the household is spiritually rich but materially poor. This area is called material poverty quadrant.

The third quadrant combines positive material needs and negative spiritual needs. The household in this area is found to be materially rich but spiritually poor. This area is called spiritual poverty quadrant. Lastly, the fourth quadrant shows the mixture between negative spiritual needs and negative material needs. It means that the household in quadrant is spiritually and materially poor. Hence, this area is called absolute poverty quadrant.

The CIBEST quadrant has, at least, two advantages. Firstly, it will be able to identify the number of households in each quadrant. Secondly, it will assist government agencies to formulate precise development policy, which is needed in order to move households living in poverty quadrants towards the welfare quadrant.

This model is based on the CIBEST Quadrant. As has been discussed above, there are four CIBEST quadrants. CIBEST model is constructed from these four quadrants. The model is composed from four indices, namely, welfare index, material poverty index, spiritual poverty index, and absolute poverty index. This sub section attempts to formulate these indices mathematically.

The first is the welfare index. This index is symbolized by W. Formula of the index is as below:

$\mathrm{W}=\frac{w}{N} \mathrm{~W}=\frac{w}{N}$

whereby:

$\mathrm{W}=$ Welfare Index; $0<\mathrm{W}<1$

$\mathrm{w}=$ the number of prosperous households (spiritually and materially rich)

$\mathrm{N}$ = total number of observed households

In this index, we simply calculate the number of households whom are 
spiritually and materially rich (w). It will be then divided by the number of total population in order to get welfare index. The value of welfare index is between 0 and 1. It is because of the impossibility of having all population in the same welfare quadrant. The second index is Material Poverty Index. This index is symbolized by Pm. Formula of Pm can be observed below.

$$
\mathrm{Pm}=\frac{\mathrm{Mp}}{\mathrm{N}} \mathrm{Pm}=\frac{\mathrm{Mp}}{\mathrm{N}} \text {. }
$$

whereby:

$\mathrm{Pm}=$ Material Poverty Index; $0<\mathrm{Pm}<1$

$\mathrm{Mp}=$ the number of materially poor but spiritually rich households

$\mathrm{N}=$ total number of observed households

We simply count the number of households living in the second quadrant of CIBEST in order to get the value of Mp. Furthermore, the third index is spiritual poverty index (Ps). Formula of this index is as follow.

$$
\mathrm{Ps}=\frac{S p}{N} \mathrm{Ps}=\frac{S p}{N}
$$

whereby:

Ps $=$ Spiritual Poverty Index; $0<$ Ps $<1$

$\mathrm{Sp}=$ the number of spiritually poor but materially rich households

$\mathrm{N}=$ total number of observed households

The value of $S p$ could be identified when the number of spiritually poor households living in the third quadrant of CIBEST is known. Lastly, the fourth index is absolute poverty index, which is symbolized by Pa. Formula of this index is as below.

$$
\mathrm{Pa}=\frac{A p}{N} \mathrm{~Pa}=\frac{A p}{N}
$$

whereby:

$\mathrm{Pa}=$ Absolute Poverty Index; $0<\mathrm{Pa}<1$

Ap $=$ the number of absolute poor households

(materially and spiritually poor)

$\mathrm{N}=$ total number of observed households

This index requires calculation of the number of absolute poor households (Ap) in order to find out the value of Pa. Nevertheless, the values of w, Mp, Sp and Ap cannot be computed unless we know the standard determining material poor and spiritual poor. Regarding these, we will develop material line as the basis to separate materially poor and materially rich households. We will also develop spiritual line as the basis to separate spiritually poor and spiritually rich households.

Material line (MV) is derived from minimum standard of material needs, which must be fulfilled by a household. Mathematical formula of this MV can be 
seen below.

$$
\mathrm{MV}=\sum_{i=1}^{n} \boldsymbol{P i} \boldsymbol{M} i \sum_{i=1}^{n} P \boldsymbol{i} \boldsymbol{M i}
$$

whereby:

$$
\begin{aligned}
\mathrm{MV}= & \text { minimum material needs standard } \\
& \text { (in terms of Rp or local currency) } \\
\mathrm{Pi}= & \text { price of goods and services } \mathrm{i} \\
& \text { (in terms of Rp or local currency) } \\
\mathrm{Mi}= & \text { minimum number of goods and services needed }
\end{aligned}
$$

\begin{tabular}{|c|c|c|c|c|c|c|}
\hline \multirow{2}{*}{ Variables } & \multicolumn{5}{|c|}{ Likert Scale } & \multirow{2}{*}{$\begin{array}{c}\text { Poverty } \\
\text { Standard }\end{array}$} \\
\hline & 1 & 2 & 3 & 4 & 5 & \\
\hline Prayer & $\begin{array}{l}\text { Blocking } \\
\text { others to } \\
\text { pray }\end{array}$ & $\begin{array}{l}\text { Against the } \\
\text { concept of } \\
\text { prayer }\end{array}$ & $\begin{array}{l}\text { Performing } \\
\text { obligatory } \\
\text { prayer but } \\
\text { not on } \\
\text { regular basis }\end{array}$ & $\begin{array}{l}\text { Always } \\
\text { performing } \\
\text { obligatory } \\
\text { prayer } \\
\text { but not in } \\
\text { congrega- } \\
\text { tional prayer }\end{array}$ & $\begin{array}{l}\text { Performing } \\
\text { congregational } \\
\text { prayer for } \\
\text { obligatory one } \\
\text { and perform } \\
\text { recommended } \\
\text { prayer }\end{array}$ & \\
\hline Fasting & $\begin{array}{l}\text { Blocking } \\
\text { others to } \\
\text { undertake } \\
\text { fasting }\end{array}$ & $\begin{array}{l}\text { Against the } \\
\text { concept of } \\
\text { fasting }\end{array}$ & $\begin{array}{l}\text { Not fully } \\
\text { performing } \\
\text { obligatory } \\
\text { fasting }\end{array}$ & $\begin{array}{l}\text { Performing } \\
\text { only } \\
\text { obligatory } \\
\text { fasting }\end{array}$ & $\begin{array}{l}\text { Performing } \\
\text { obligatory } \\
\text { fasting and } \\
\text { recommendable } \\
\text { fasting }\end{array}$ & $\begin{array}{l}\text { Average } \\
\text { score for }\end{array}$ \\
\hline $\begin{array}{l}\text { Zakat } \\
\text { and Infak }\end{array}$ & $\begin{array}{l}\text { Blocking } \\
\text { others to } \\
\text { pay zakat } \\
\text { and infak }\end{array}$ & $\begin{array}{l}\text { Against the } \\
\text { concept of } \\
\text { zakat and } \\
\text { infak }\end{array}$ & $\begin{array}{l}\text { Not paying } \\
\text { infak at least } \\
\text { once in a } \\
\text { year }\end{array}$ & $\begin{array}{l}\text { Paying zakat } \\
\text { al-fitrand } \\
\text { zakat al-maal }\end{array}$ & $\begin{array}{l}\text { Paying zakat } \\
\text { al-fitr, zakat al- } \\
\text { maal, and infak }\end{array}$ & $\begin{array}{l}\text { spiritually } \\
\text { poor } \\
\text { household } \\
\text { is equal } \\
\text { to } 3\end{array}$ \\
\hline $\begin{array}{l}\text { House- } \\
\text { hold } \\
\text { Environ- } \\
\text { ment }\end{array}$ & $\begin{array}{l}\text { Forbid } \\
\text { ibaadah }\end{array}$ & $\begin{array}{l}\text { Against } \\
\text { implemen- } \\
\text { tation of } \\
\text { ibaadah }\end{array}$ & $\begin{array}{l}\text { Consider } \\
\text { ibaadahas } \\
\text { private } \\
\text { matter for } \\
\text { household } \\
\text { member }\end{array}$ & $\begin{array}{l}\text { Support } \\
\text { execution of } \\
\text { ibaadah }\end{array}$ & $\begin{array}{l}\text { Creating } \\
\text { environment } \\
\text { which obligates } \\
\text { execution of } \\
\text { ibaadah }\end{array}$ & $(\mathrm{SV}=3)$ \\
\hline $\begin{array}{l}\text { Govern- } \\
\text { ment } \\
\text { Policy } \\
\text { Environ- } \\
\text { ment }\end{array}$ & $\begin{array}{l}\text { Forbid } \\
\text { ibaadah }\end{array}$ & $\begin{array}{l}\text { Against } \\
\text { implemen- } \\
\text { tation of } \\
\text { ibaadah }\end{array}$ & $\begin{array}{l}\text { Consider } \\
\text { ibaadahas } \\
\text { private } \\
\text { matter }\end{array}$ & $\begin{array}{l}\text { Support } \\
\text { execution of } \\
\text { ibaadah }\end{array}$ & $\begin{array}{l}\text { Creating } \\
\text { environment } \\
\text { which obligates } \\
\text { execution of } \\
\text { ibaadah }\end{array}$ & \\
\hline
\end{tabular}

Table 1. Spiritual Needs Indicator

Based on the equation (5) above, a household is called materially poor when income of that household is less than the MV value. Otherwise, the household is classified materially rich. However, the MV formula is not sufficient. We need to have spiritual line formula. 
Spiritual line (SV) is derived from five variables explained in the above sub section. It is the line showing actual spiritual condition of the households. Likert scale is used to assist the evaluation of household spiritual condition. Table 1 provides the indicators of the five variables of spiritual needs.

Based on the Table 1, the Likert scale used is ranging from 1 to 5 . The value of 1 shows the worst indicator while that of 5 indicates the best condition. Spiritual standard, which separates spiritually poor households and spiritually rich households, is determined to be equal to 3. Mathematically, it can be written as follow.

$\mathrm{SV}=3$

whereby:

SV = absolute line (standard) for spiritual poverty

The value of SV is based on three arguments. Firstly, for prayer and fasting needs, the value of 3 shows that a person intentionally leaves his obligation in one time, and in other time, he performs his obligations. In Islam, leaving our obligation intentionally will be considered as sinful acts, which reduce spiritual quality of a person. Secondly, for zakat and infak payment, the value of 3 indicates that a person has no intention to pay infak, even once in a year. Although paying infak is not obliged for the poor, but we believe that even the poorest of the poor will also have capability to pay infak. For example, a poor household should be able to pay infak USD 1 per annum. It is a very minimum amount. Therefore, this score is made as spiritual line.

Thirdly, as for household environment and government policy environment, the score of 3 shows separation between worldly affairs and akheeraaffairs. There is no effort to encourage household members to execute ibaadahsince ibaadahis considered as private matter. It means that it is up to the household members whether they want to perform their religious obligation or not.

We can also calculate general spiritual condition of households in one country. The formula to compute it is as below.

$$
\begin{aligned}
& \mathrm{SS}=\sum_{k=1}^{n} \frac{S H k}{N} \mathrm{SS}=\sum_{k=1}^{n} \frac{S H k}{N} \\
& \text { whereby: } \\
& \text { SS = Average score of actual spiritual condition of the observed } \\
& \text { households } \\
& \mathrm{SH}_{\mathrm{k}}=\text { Actual spiritual condition of the household } k \\
& \mathrm{~N}=\text { Total number of observed households }
\end{aligned}
$$

If the value of $S S>S V$, then generally speaking, spiritual condition of 
population in one country is in good condition. In other words, they are spiritually rich. Similarly, if the value of SS $\leq$ SV, the residents of that country are spiritually poor. Another important aspect is related on the calculation of $\mathrm{SH}_{\mathrm{k}}$. It is obtained from the score of all variables observed in the household. Therefore, equation (8) below provides the formula to compute $\mathrm{SH}_{\mathrm{k}}$.

$$
\begin{aligned}
& \mathrm{SH}=\sum_{\text {whereby: }}^{n} \frac{H 1+H 2+\cdots+H n}{M H} \mathrm{SH}=\sum_{h=1}^{n} \frac{H 1+H 2+\cdots+H n}{M H} \\
& \mathrm{SH} \quad=\text { average score of actual spiritual condition of one household } \\
& \mathrm{Hh} \quad=\text { actual spiritual score of household member } h \\
& \mathrm{MH} \quad=\text { total number of household members }
\end{aligned}
$$

As for $\mathrm{Hi}$, its formula is as below:

$$
\mathrm{Hi}=\frac{V p+V f+V z+V h+V g}{5} \mathrm{Hi}=\frac{V p+V f+V z+V h+V g}{5} . .
$$

whereby:

$$
\begin{aligned}
\mathrm{Hi} & =\text { actual spiritual score of household member } i \\
\mathrm{Vp} & =\text { prayer score } \\
\mathrm{Vf} & =\text { fasting score } \\
\mathrm{Vz} & =\text { score of zakat and infak } \\
\mathrm{Vh} & =\text { score of household environment } \\
\mathrm{Vg} & =\text { score of government policy environment }
\end{aligned}
$$

Determination of the number of households in each CIBEST quadrant is based on combination of results of MV standard and SV standard. There are four probabilities of combination between MV and SV results (vide Table 2).

Table 2. Combination of MV and SV Values

\begin{tabular}{ccc}
\hline Results & $\leq$ MV value & $>$ MV value \\
\hline SV value & Materially Poor and & Materially and Spiritually \\
& Spiritually Rich Household & Rich Household \\
(Quadrant II) & (Quadrant I) \\
$\leq$ SV value & $\begin{array}{c}\text { Materially and Spiritually } \\
\text { Poor Household }\end{array}$ & Materially Rich and \\
& (Quadrant IV) & Spiritually Poor Household \\
(Quadrant III)
\end{tabular}

When the number of household in each quadrant is known, then calculation of all indices is easy to conduct. Combining all values of welfare index, material poverty index, spiritual poverty index and absolute poverty index, we will get total values of those indices to be equal to 1 . This is called as the generalized CIBEST model. 


\section{CIBEST Model $=\mathbf{1}=\mathbf{W}+\mathbf{P m}+\mathbf{P s}+\mathbf{P a}$.}

Total summation of all indices must be equal to one. These indices could be utilized in mapping the population, in which quadrant that most of the population live. It will assist the government to design policy strategy that can be effectively executed. Let us proceed to the following sub-section in order to understand computation of these indices.

In this illustration, there are two basic assumptions which must be fulfilled. Firstly, the collected data must be primary data. Secondly, method of obtaining data must be census or sampling.

There are four stages of calculating these indices. Firstly, compute the value of $\mathrm{MV}$, while that of $\mathrm{SV}$ is already given, i.e. 3. This $\mathrm{MV}$ value may be taken from official data of the observed country. In case available official data is on individual basis, we need to transform the data into household basis. For example, if USD 100 is found to be the individual poverty line and 4 person is the average size of a household, then multiplication of USD 100 and 4 person will yield household material line or MV value. Secondly, calculate the value of SH and monthly income of the observed households. Thirdly, put the observed households in the CIBEST quadrant whether they are in the first, second, third or fourth quadrant by using Table 2 as reference. Fourthly, calculate all indices by using available data.

In order to understand deeper, let us begin with an Islamic state. Assume that there exist 10 households living in the country. Regarding the MV value, let us assume that the MV standard is equal to USD 150. This MV standard may vary across countries. In our case, this assumption of MV value is needed in order to ease the calculation. As for SV, it is equal to 3. The actual condition of these 10 households is portrayed in the Table 3. They have different number of household member. Assume that we have conducted survey on them in order to find out their actual spiritual condition as well as their actual income.

Table 3. Actual Spiritual and Material Condition of the Observed Households

\begin{tabular}{cccccc}
\hline $\begin{array}{c}\text { Household } \\
\text { Number }\end{array}$ & $\begin{array}{c}\text { Household } \\
\text { Member }\end{array}$ & SH & $\begin{array}{c}\text { Household } \\
\text { Incomel } \\
\text { Month }\end{array}$ & Status & $\begin{array}{c}\text { CIBEST } \\
\text { Quadrant }\end{array}$ \\
\hline$\# 1$ & 5 members & 3.8 & USD 270 & $\begin{array}{l}\text { Spiritually and } \\
\text { materially rich }\end{array}$ & Quadrant I \\
$\# 2$ & 7 members & 2.9 & USD 500 & $\begin{array}{l}\text { Spiritually } \\
\text { poor and } \\
\text { materially rich }\end{array}$ & Quadrant III \\
\end{tabular}




\begin{tabular}{|c|c|c|c|c|c|}
\hline$\# 3$ & 3 members & 2.4 & USD 100 & $\begin{array}{l}\text { Spiritually } \\
\text { and materially } \\
\text { poor }\end{array}$ & Quadrant IV \\
\hline$\# 4$ & 4 members & 1.9 & USD 50 & $\begin{array}{l}\text { Spiritually } \\
\text { and materially } \\
\text { poor }\end{array}$ & Quadrant IV \\
\hline$\# 5$ & 3 members & 4.2 & USD 600 & $\begin{array}{l}\text { Spiritually and } \\
\text { materially rich }\end{array}$ & Quadrant I \\
\hline$\# 6$ & 3 members & 4.5 & USD 100 & $\begin{array}{l}\text { Spiritually rich } \\
\text { and materially } \\
\text { poor }\end{array}$ & Quadrant II \\
\hline$\# 7$ & 3 members & 3.7 & USD 50 & $\begin{array}{l}\text { Spiritually rich } \\
\text { and materially } \\
\text { poor }\end{array}$ & Quadrant II \\
\hline$\# 8$ & 6 members & 2.3 & USD 100 & $\begin{array}{l}\text { Spiritually } \\
\text { and materially } \\
\text { poor }\end{array}$ & Quadrant IV \\
\hline$\# 9$ & 7 members & 3.6 & USD 50 & $\begin{array}{l}\text { Spiritually rich } \\
\text { and materially } \\
\text { poor }\end{array}$ & Quadrant II \\
\hline \#10 & 3 members & 1.5 & USD 350 & $\begin{array}{l}\text { Spiritually } \\
\text { poor and } \\
\text { materially rich }\end{array}$ & Quadrant III \\
\hline
\end{tabular}

Given the information provided in the Table 3, we can calculate the value of each index. Let us start with Welfare Index. Total number of observed households or $\mathrm{N}$ is equal to 10 , while the value of $\mathrm{w}$ is equal to 2 . By using equation (1), we will obtain:

$$
\mathrm{W}=2 / 10=0.2
$$

Interpretation of this index is that there 20 percent of the households in the country whom are spiritually and materially rich. Furthermore, the Table 3 provides information on the values of $\mathrm{Mp}, \mathrm{Sp}$, and $\mathrm{Ap}$, respectively. It is known that $\mathrm{Mp}=$ 3, $S p=2$, and $A p=3$. From these data, we can calculate Material Poverty Index, Spiritual Poverty Index and Absolute Poverty Index. They are as below.

$$
\begin{aligned}
& \mathrm{Pm}=3 / 10=0.3 \\
& \mathrm{Ps}=2 / 10=0.2 \\
& \mathrm{~Pa}=3 / 10=0.3
\end{aligned}
$$

It can be interpreted that 30 percent of the population live in material poverty, while 20 percent live under spiritual poverty. The remaining 30 percent live in the absolute poverty condition. General CIBEST model will be equal to:

CIBEST Model $=\mathrm{W}+\mathrm{Pm}+\mathrm{Ps}+\mathrm{Pa}=0.2+0.3+0.2+0.3=1$ 
This information should be utilized by policy maker in the country. Some policy implications may arise from this illustration. In the first priority, Islamic government should focus on those living in the fourth quadrant as the primary target of development programs. These programs must be designed not only by targeting material progress but also spiritual progress. Second priority is the second quadrant, in which the households are materially poor and spiritually rich. Providing financial access and technical assistance may become the solution. Third priority is the third quadrant. Those who are in this quadrant can be requested to fulfil their religious obligation, such aspaying zakat, in order to purify their spiritual condition. The ultimate objective of the government is on how to move the people living in these quadrants to the first quadrant, which is welfare area.

\section{Conclusion}

From the discussion and analysis above, some conclusions can be drawn. Firstly, poverty and welfare concepts in the Islamic perspective are not only seen from material dimension, but also spiritual dimension. However, various indicators prevailing in many parts of the world including Islamic countries seem to focus only on material progress. Lack of attention towards spiritual progress is still becoming development issue that needs to be overcome.

Secondly, attempts to construct various indicators determining level of poverty and prosperity in an Islamic countries should be encouraged since these indicators could be used as development signal whether it is success or not. Regarding this, this paper has attempted to develop four indices, namely, welfare index, material poverty index, spiritual poverty index, and absolute poverty index. These indices are based on the concept of CIBEST quadrant, which represents Islamic concept on poverty and prosperity.

Thirdly, the presence of CIBEST quadrant and CIBEST model produces policy implications, which are expected to be beneficial for Islamic government in providing direction of development. Main target of development program is on how to mobilize households to the welfare quadrant, in which households are spiritually and materially rich.

However, this study has also limitation. Unless the Muslim minority living in non-Islamic countries attempt to use this model in order to observe their actual poverty and welfare level, CIBEST model may only be applied in the Islamic countries. Future research on the possibility to implement Islamic concept of poverty and welfare level should be prioritized as an important agenda. 


\section{References}

Ahmed, H. 2004. Role of Zakat and Awqaf in Poverty Alleviation. Jeddah: IRTIIDB.

Al Ghazali. 1980. IhyaUlum al Din. Beirut: DarulFikr.

Al-Qardawi, Y. 1993. Fiqhuz Zakat. Jakarta: LiteraAntarNusa.

-. 2002. Zakat Role in Curing Social and Economic Malaises. In M. Kahf, (Ed). Economics of Zakat. Jeddah: IRTI - IDB.

Alimoeso, S. 2014. Utilization of Family Data in the Development of Family. Paper presented at National Zakat Conference of BAZNAS, Balikpapan.

Badan Amil Zakat Nasional. 2013. Zakah Report. Jakarta: BAZNAS

Beik, I.S. 2013. Economic Role of Zakat in Reducing Poverty and Income Inequality: A Case Study in the Province of DKI Jakarta, Indonesia. Germany: Lambert Academic Publishing.

Chapra, M.U. 2008. The Islamic Vision of Development in the Light of Maqasid AlShariah. Jeddah: IRTI IDB.

Hafidhuddin, D. 2013. The Poverty Concept on Islamic Analysis. Paper presented National Focus Group Discussion on Islamic Poverty Line, Bogor.

Islahi, A. A. 1992. Economic Thought of Ibn Al-Qayyim. in A.M. Sadeq \& A. Ghazali. (ed), Readings in Islamic Economic Thought. Petaling Jaya: Longman Malaysia.

Pramanik, A.H. 1993. Development and Distribution in Islam. Petaling Jaya: Pelanduk Publications.

1998. Poverty from Multidimensional Perspectives: A Micro Level Study of Seven Malaysian Kampungs (Villages). Kuala Lumpur: CahayaPantai

Rasool, M.S.A, et.al. 2011. Using Shariah Indicators to Analyse Poverty: Experience from Malaysian Zakat Institutions. Paper presented at International Zakat Conference held by World Zakat Forum, BAZNAS, and IPB, Bogor.

Rehman, A. 1980. Economic Doctrine of Islam. Lahore: Islamic Publications Limited.

Sadeq, A. M. \& A. Ghazali (eds). 1992. Readings in Islamic Economic Thought. Petaling Jaya: Longman Malaysia.

Shirazi, N.S. 1994. An Analysis of Pakistan's Poverty Problem and Its Alleviation through Infaq. (Dissertation Unpublished). Islamabad: International Islamic University, Islamabad.

Sudarwati, N. 2009. The Povery Alleviation Program. Malang: Intimedia

Suharto, E. 2009. Poverty and Social Insurance in Indonesia: The Idea About Universal Social Insurance in Health. Bandung: Alfabeta. 